\title{
ANALISIS PENGARUH KUALITAS PELAYANAN, PRODUK, HARGA, DAN LOKASI TERHADAP KEPUASAN NASABAH (STUDI KASUS PADA PT BANK RAKYAT INDONESIA (PERSERO) Tbk. UNIT NGESREP SEMARANG)
}

\author{
Rizka Putri Rumastari*) \\ Aris Sunindyo**) \\ *) putririzka494@gmail.com
}

\begin{abstract}
This study aims to determine and analyze the effects of service quality, product, price, and place towards the customers satisfaction (Case Study at PT Bank Rakyat Indonesia (Persero) Tbk. Unit Ngesrep Semarang) both simultaneously or partially.

The population in this study are all the customers at PT Bank Rakyat Indonesia (Persero) Tbk. Unit Ngesrep Semarang. The data used in the research are primary and secondary data. The sample used of 100 respondents collected through the questionnaire by following the accidental sampling technique. Data analysis model using Multiple Linear Regression Analysis Model. Meanwhile, data analysis techniques use Statistical F Test, Coefficient of Determination Test (Adjusted $R$ Square), and Statistical $t$ Test.

The result of the analysis and discussion show that the variables of service quality, product, price, and place simultaneously have a significant effects towards the customers satisfaction at PT Bank Rakyat Indonesia (Persero) Tbk. Unit Ngesrep Semarang. Partially, the variables of service quality, product, price, and place each have a positive and significant effect towards the customer satisfaction at PT Bank Rakyat Indonesia (Persero) Tbk. Unit Ngesrep Semarang.
\end{abstract}

Keywords: Customers Satisfaction, Service Quality, Product, Price, Place

*) Mahasiswa Tugas Akhir Prodi Keuangan dan Perbankan, Jurusan Akuntansi, Politeknik Negeri Semarang

**) Dosen Jurusan Akuntansi, Politeknik Negeri Semarang

\section{PENDAHULUAN}

\section{Latar Belakang Masalah}

Dalam dunia modern sekarang ini, peranan perbankan dalam memajukan perekonomian suatu negara sangatlah besar. Hampir semua sektor yang berhubungan dengan berbagai kegiatan keuangan selalu membutuhkan jasa bank (Kasmir, 2012:3). Dapat dilihat bahwa ketika perekonomian Indonesia mengalami penurunan atau melemah, sektor perbankan terkena imbas dari melemahnya ekonomi Indonesia. Begitu pentingnya dunia perbankan, sehingga ada anggapan bahwa bank merupakan "nyawa" untuk menggerakkan roda perekonomian suatu negara (Kasmir, 2012:3).

Perkembangan bank sendiri saat ini sudah sangat pesat. Bank-bank banyak bermunculan di Indonesia, baik itu bank konvensional maupun bank syariah. Bank konvensional dan bank syariah di Indonesia sama-sama berlomba-lomba dan bersaing menjadi bank terbaik yang dibutuhkan oleh nasabah. Mereka berusaha untuk mendapatkan nasabah yang banyak dari 
berbagai kalangan masyarakat karena kepuasan nasabah merupakan hal terpenting dalam sebuah bank. Kepuasan nasabah merupakan kunci kesuksesan suatu usaha yang dilakukan oleh bank karena bank memiliki banyak produk yang dipasarkan maka banyak pula usaha yang harus dilakukan bank untuk memberikan kepuasan kepada nasabahnya.

Kepuasan Nasabah. Menurut Tjiptono (2002:24), kepuasan konsumen adalah perbedaan antara harapan dan kinerja atau jasa yang dirasakan. Sedangkan, menurut Kotler dan Keller (dalam Huda dan Farida, 2014), kepuasan konsumen adalah perasaan senang atau kecewa seseorang yang muncul setelah membandingkan antara kinerja (hasil) produk yang dipikirkan terhadap kinerja yang diharapkan.

Kepuasan nasabah dapat dipengaruhi oleh beberapa faktor, di antaranya yaitu kualitas pelayanan, produk, harga, dan lokasi. Keempat faktor tersebut yang dapat memengaruhi kepuasan nasabah dan masing-masing memiliki beberapa indikator di dalamnya.

Kualitas Pelayanan. Menurut Juwandi (dalam Ghozali, 2014), faktor-faktor yang memengaruhi kepuasan pelanggan salah satunya adalah kualitas pelayanan atau service quality, kepuasan terhadap kualitas pelayanan biasanya sulit ditiru. Kualitas pelayanan merupakan kendali yang mempunyai banyak dimensi, salah satunya yang populer adalah SERVQUAL.

Kualitas Produk. Menurut Tjiptono (dalam Windarti dan Ibrahim, 2017), kualitas produk adalah suatu kondisi dinamis yang berhubungan dengan produk, jasa, manusia, proses, dan lingkungan yang memenuhi atau melebihi harapan. Menurut Purnama (dalam Windarti dan Ibrahim, 2017), kualitas produk adalah kesesuaian antara kebutuhan dan keinginan atas produk ke dalam spesifikasi produk yang dihasilkan.

Harga. merupakan faktor ketiga yang dapat memengaruhi kepuasan nasabah. Menurut Kotler dan Amstrong (dalam Ghozali, 2014), harga adalah sejumlah uang yang dibayarkan atas jasa, atau jumlah nilai yang konsumen tukar dalam rangka mendapatkan manfaat dari memiliki atau menggunakan barang atau jasa.

Lokasi. Menurut Tjiptono (2011:190), lokasi fasilitas jasa seringkali tetap merupakan faktor krusial yang berpengaruh terhadap kesuksesan suatu jasa, karena lokasi erat kaitannya dengan pasar potensial penyedia jasa.

Dengan memahami kebutuhan dan mengukur kepuasan atas kualitas pelayanan, produk, harga, dan lokasi merupakan salah satu hal yang penting dilakukan oleh PT Bank Rakyat Indonesia (Persero) Tbk. Unit Ngesrep Semarang. Dengan mengetahui tingkat kepuasan nasabah maka PT Bank Rakyat Indonesia (Persero) Tbk. Unit Ngesrep Semarang akan mengetahui posisinya dalam persaingan bisnis. Selanjutnya, akan lebih mudah dalam 
mengambil kebijakan berimplementasi-kan strategi untuk meningkatkan kepuasan nasabah melalui kualitas pelayanan, produk, harga, dan lokasi. Empat faktor tersebut merupakan hal yang menentukan kepuasan nasabah. Kepuasan nasabah sangatlah penting karena dengan nasabah merasa puas dengan pelayanan, produk, harga, dan lokasi dari bank, maka kelangsungan bank tersebut akan berjalan baik.

Berdasarkan penelitian yang dilakukan oleh Ghozali (2014), menyebutkan bahwa hasil uji, baik uji secara simultan, parsial, maupun uji koefisien determinasi, kualitas pelayanan terhadap kepuasan nasabah adalah positif dan signifikan, serta kualitas pelayanan tersebut dapat menjelaskan kepuasan nasabah. Didukung oleh penelitian yang dilakukan oleh Ningrum (2015), dan Nuriscasani (2017) yang menyatakan, bahwa kualitas layanan berpengaruh positif dan signifikan terhadap kepuasan nasabah. Namun, pada penelitian yang dilakukan oleh Huda (2016) menyatakan, bahwa kualitas layanan secara parsial tidak berpengaruh signifikan terhadap kepuasan nasabah.

Penelitian yang dilakukan oleh Lubis (2014), mengenai faktor kedua yakni kualitas produk, menyatakan bahwa produk berpengaruh positif dan signifikan terhadap kepuasan pelanggan, sehingga apabila kualitas produk ditingkatkan maka kepuasan pelangganpun akan meningkat. Penelitian ini sejalan dengan penelitian yang dilakukan Ningrum (2015), Huda (2016), dan Nuriscasani (2017). Namun, pada penelitian Markoni (2011), dimensi produk menunjukkan pengaruh yang negatif terhadap kepuasan nasabah.

Penelitian yang dilakukan oleh Nuriscasani (2017), menyatakan bahwa harga memiliki pengaruh positif dan signifikan terhadap kepuasan nasabah. Penelitian ini didukung oleh penelitian yang dilakukan oleh Ghozali (2014), Lubis (2014), Ningrum (2016), dan Firdiyansyah (2017). Ghozali (2014), meneliti dengan dua variabel bebas yakni kualitas layanan dan harga, hasilnya menyatakan bahwa harga tidak lebih dominan pengaruhnya terhadap kepuasan nasabah dibanding dengan kualitas layanan.

Penelitian yang dilakukan oleh Wijayaningratri dan Budiyono (2015), menyatakan bahwa variabel lokasi mempunyai pengaruh signifikan dan positif yang menunjukkan adanya hubungan yang searah antara variabel lokasi dengan kepuasan nasabah. Penelitian ini didukung oleh penelitian yang dilakukan oleh Huda dan Farida (2014), Sari dan Soliha (2018), dan Firdiyansyah (2017). Namun, pada penelitian Manampiring et al. (2016), menyatakan bahwa variabel lokasi tidak berpengaruh terhadap kepuasan nasabah.

Berdasarkan penjelasan teori dan fenomena-fenomena bisnis yang terjadi, dengan didukung adanya penelitian-penelitian terdahulu beserta research gap. Penelitian ini dibuat 
untuk mengkaji lebih lanjut mengenai tingkat kepuasan nasabah PT Bank Rakyat Indonesia (Persero) Tbk. Unit Ngesrep Semarang.

\section{Rumusan Masalah dan Tujuan Penelitian}

Berdasarkan uraian yang telah dijabarkan di dalam latar belakang, masalah dalam peneitian ini adalah apakah pengaruh variabel-variabel Kualitas Pelayanan, Produk, Harga, dan Lokasi baik secara parsial maupun simultan berpengaruh signifikan Terhadap Kepuasan Nasabah Pada PT Bank Rakyat Indonesia (Persero) Tbk Unit Ngesrep Semarang?.

Sedangkan, tujuan dari penelitian ini adalah untuk mengetahui dan menganalisis signifikansi pengaruh Kualitas Pelayanan, Produk, Harga, dan Lokasi baik secara parsial maupun simultan berpengaruh signifikan Terhadap Kepuasan Nasabah Pada PT Bank Rakyat Indonesia (Persero) Tbk Unit Ngesrep Semarang.

\section{KAJIAN TEORI}

\section{Kepuasan Nasabah}

Menurut Tjiptono (2002:24), kepuasan konsumen adalah perbedaan antara harapan dan kinerja atau jasa yang dirasakan. Sedangkan, menurut Kotler dan Keller (dalam Huda dan Farida, 2014), kepuasan konsumen adalah perasaan senang atau kecewa seseorang yang muncul setelah membandingkan antara kinerja (hasil) produk yang dipikirkan terhadap kinerja yang diharapkan.

\section{Faktor-faktor yang mempengaruhi Kepuasan Nasabah}

Menurut Ratnasari dan Aksa (2011:117), untuk menentukan tingkat kepuasan pelanggan ada lima faktor yang harus diperhatikan oleh perusahaan yaitu sebagai berikut:

1. Kualitas Produk. Pelangan akan merasa puas bila hasil evaluasi mereka menunjukkan bahwa produk yang mereka gunakan berkualitas.

2. Kualitas Pelayanan. Pada industri jasa, adalah mutlak bahwa pelanggan akan merasa puas bila mereka mendapatkan pelayanan yang baik atau sesuai dengan yang pelanggan harapkan.

3. Emosional. Pelanggan akan merasa bangga dan mendapatkan keyakinan bahwa orang lain akan kagum terhadap dia bila menggunakan produk dengan merek tertentu, sehingga membuatnya mengalami tingkat kepuasan yang lebih tinggi. Kepuasan yang diperoleh bukan karena kualitas dari produk, tetapi nilai sosial atau self-esteem yang membuat pelanggan menjadi puas terhadap merek tertentu. 
4. Harga. Produk yang mempunvai kualitas yang sama dengan produk lain, tetapi ditetapkan pada harga yang lebih murah akan nilai yang lebih tinggi kepada memberikan pelanggannya.

5. Biaya. Pelanggan yang tidak perlu mengeluarkan biaya tambahan atau tidak perlu membuang waktu untuk mendapatkan suatu produk/jasa (pengorbanannya semakin kecil), cenderung puas terhadap produk/jasa ini.

\section{Kualitas Pelayanan}

Menurut Wyckof dalam Lovelock (dalam Ghozali, 2014), kualitas pelayanan merupakan tingkat keunggulan (excellence) yang diharapkan dan pengendalian atas keunggulan tersebut untuk memenuhi keinginan pelanggan.

Parasuraman et al. (dalam Lupiyoadi, 2013:216), menyatakan bahwa terdapat lima dimensi SERVQUAL sebagai berikut:

1. Berwujud (Tangible) yaitu kemampuan suatu perusahaan dalam menunjukkan eksistensinya kepada pihak eksternal. Penampilan dan kemampuan sarana dan prasarana fisik perusahaan dan keadaan lingkungan sekitarnya adalah bukti nyata dari pelayanan yang diberikan oleh pemberi jasa, meliputi fasilitas fisik (gedung, gudang, dan lain sebagainya), perlengkapan dan peralatan yang dipergunakan (teknologi), serta penampilan pegawainya.

2. Keandalan (Reliability) yaitu kemampuan perusahaan untuk memberikan pelayanan sesuai yang dijanjikan secara akurat dan terpercaya. Kinerja harus sesuai dengan harapan pelanggan yang berarti ketepatan waktu, pelayanan yang sama untuk semua pelanggan tanpa kesalahan, sikap yang simpatik, dan dengan akurasi yang tinggi.

3. Daya Tanggap (Responsiveness) yaitu suatu kebijakan untuk membantu dan memberikan pelayanan yang cepat (responsif) dan tepat kepada pelanggan, dengan penyampaian informasi yang jelas. Membiarkan pelanggan menunggu menciptakan persepsi yang negatif dalam kualitas pelayanan.

4. Jaminan dan Kepastian (Assurance) yaitu pengetahuan, kesopansantunan, dan kemampuan para pegawai perusahaan untuk menumbuhkan rasa percaya para pelanggan kepada perusahaan. Terdiri dari beberapa komponen antara lain komunikasi (Communication), kredibilitas (Credibility), keamanan (Security), kompetensi (Competent), dan sopan santun (Courtesy).

5. Empati (Empathy) yaitu memberikan perhatian yang tulus dan bersifat individual atau pribadi yang diberikan kepada para pelanggan dengan berupaya memahami keinginan mereka. Hal ini mengharapkan bahwa suatu perusahaan memiliki pengertian dan 
pengetahuan tentang pelanggan, memahami kebutuhan pelanggan secara spesifik, serta memiliki waktu pengoperasian yang nyaman bagi pelanggan.

\section{Produk}

Menurut Tjiptono (2002:95), produk merupakan segala sesuatu yang dapat ditawarkan produsen untuk diperhatian, diminta, dicari, dibeli, digunakan, atau dikonsumsi pasar sebagai pemenuhan kebutuhan atau keinginan pasar yang bersangkutan

Dimensi kualitas produk menurut Tjiptono dalam Windarti dan Ibrahim (2017), dimensi kualitas produk adalah sebagai berikut:

1. Hasil Produk (Performance). Karakteristik operasi pokok dari produk inti (core product) yang dibeli kinerja dari produk yang memberikan manfaat bagi konsumen yang mengkonsumsi sehingga konsumen dapat memperoleh manfaat dari produk yang telah dikonsumsi.

2. Ciri-ciri atau keistimewaan tambahan (Features) merupakan karakteristik sekunder atau pelengkap dari produk inti keistimewaan tambahan produk juga dapat dijadikan ciri khas yang membedakan dengan produk pesaing yang sejenis. Ciri khas yang ditawarkan juga dapat memengaruhi tingkat kepuasan konsumen terhadap suatu produk.

3. Kehandalan (Reliability). Kemungkinan kecil terhadap suatu kegagalan pakai atau kerusakan tingkat risiko kerusakan produk, menentukan tingkat kepuasan konsumen yang diperoleh dari suatu produk. Semakin besar risiko yang diterima oleh konsumen terhadap produk, semakin kecil tingkat kepuasan yang diperoleh konsumen.

4. Kesesuaian dengan Spesifikasi (Conformance to Specification) yaitu kesesuaian kinerja dan kualitas produk dengan standar yang diinginkan. Pada dasarnya, setiap produk memiliki standar ataupun spesifikasi yang telah ditentukan. Karakteristik desain operasi memenuhi standar-standar yang telah ditetapkan sebelumnya.

5. Daya Tahan (Durability). Berkaitan dengan berapa lama produk tersebut dapat digunakan. Daya tahan biasanya berlaku untuk produk yang bersifat dapat dikonsumsi dalam jangka panjang.

6. Kegunaan (Service Ability) meliputi kecepatan, kompetensi, kenyamanan, mudah direparasi serta penanganan keluhan yang memuaskan.

7. Estetika (Aesthetics). Daya tarik produk terhadap panca indera. Konsumen akan tertarik terhadap suatu produk ketika konsumen melihat tampilan awal dari produk tersebut. 
8. Kualitas yang dirasakan (Perceived Quality). Kualitas yang dirasakan adalah kesan kualitas suatu produk yang dirasakan oleh konsumen. Dimensi kualitas ini berkaitan dengan persepsi konsumen terhadap kualitas sebuah produk ataupun merk.

\section{Harga}

Menurut Tjiptono (2002:151), harga merupakan satu-satunya unsur bauran pemasaran yang memberikan pemasukan atau pendapatan bagi perusahaan, sedangkan ketiga unsur lainnya (produk, distribusi, dan promosi) menyebabkan timbulnya biaya (pengeluaran). Disamping itu, harga merupakan unsur bauran pemasaran yang bersifat fleksibel, artinya dapat diubah dengan cepat.

Indikator harga diketahui sebagai berikut:

1. Biaya Administratif

2. Setoran Minimal Tabungan

3. Setoran Awal Tabungan

\section{Lokasi}

Lokasi adalah keputusan yang dibuat perusahaan berkaitan dengan dimana operasi dan stafnya akan ditempatkan (Lupiyoadi dan Hamdani, 2009:92).

Menurut Tjiptono (2011:190), lokasi fasilitas jasa seringkali tetap merupakan faktor krusial yang berpengaruh terhadap kesuksesan suatu jasa, karena lokasi erat kaitannya dengan pasar potensial penyedia jasa.

Lokasi diukur dengan indikator menurut Tjiptono (2016:93), sebagai berikut:

1. Akses, yaitu lokasi yang dilalui mudah dijangkau sarana transportasi umum.

2. Visibilitas, yaitu lokasi atau tempat yang dapat dilihat dengan jelas dari jarak pandang normal.

3. Lalu-lintas (Traffic), menyangkut dua pertimbangan utama:

a. Banyak orang yang berlalu-lalang bisa memberikan peluang besar terhadap terjadinya impulse buying, yaitu keputusan pembelian yang seringkali terjadi spontan, tanpa perencanaan, dan/atau tanpa melalui usaha-usaha khusus.

b. Kepadatan dan kemacetan lalu lintas bisa pula menjadi hambatan, misalnya terhadap layanan kepolisian, pemadam kebakaran, atau ambulans.

4. Tempat parkir yang luas, nyaman, aman, baik untuk kendaraan roda dua maupun roda empat.

5. Ekspansi, yaitu tersedia tempat yang cukup luas untuk perluasan usaha di kemudian hari.

6. Lingkungan, yaitu daerah sekitar yang mendukung jasa yang ditawarkan. 
7. Kompetisi, yaitu lokasi pesaing. Dalam menentukan lokasi sebuah usaha, perlu dipertimbangkan apakah di jalan atau daerah tersebut telah terdapat banyak usaha yang sejenis atau tidak.

8. Peraturan Pemerintah yang berisi ketentuan untuk mengatur lokasi dari sebuah usaha-usaha tertentu, misalnya bengkel kendaraan bermotor dilarang berlokasi yang terlalu berdekatan dengan tempat ibadah.

\section{PENGARUH ANTAR VARIABEL}

Menurut Tjiptono (2012:65), penilaian pelanggan terhadap kualitas jasa adalah hasil perbandingan antara harapan (sebelum menerima jasa) dan pengalaman mereka (setelah menerima jasa). Kualitas pelayanan merupakan tolok ukur dalam menentukan penggunaan atau tidaknya seorang pengguna jasa, karena melalui kualitas pelayanan dapat diketahui kinerja dan dirasakan puas atau tidaknya para konsumen dengan layanan yang diberikan oleh penyedia jasa. Menurut Zeithmal dan Bitner (2003:156), yaitu nasabah akan merasa puas apabila mereka mendapatkan pelayanan yang baik atau sesuai dengan yang diharapkan.

Teori di atas dikuatkan oleh hasil penelitian Ghozali (2014), Wijayaningratri dan Budiyanto (2015), Ningrum (2015), dan Nuriscasani (2017) yang mengungkapkan bahwa Kualitas Pelayanan secara parsial berpengaruh signifikan terhadap Kepuasan Nasabah.

\section{Pengaruh Produk terhadap Kepuasan Nasabah}

Menurut Irwan (2004:37), kualitas produk adalah nasabah akan merasa puas jika setelah membeli dan menggunakan produk tersebut ternyata kualitas produknya baik. Menurut Zeithmal dan Bitner (2003:156), yaitu konsumen akan merasa puas apabila hasil mereka menunjukan bahwa produk yang mereka gunakan berkualitas.

Teori di atas dikuatkan oleh hasil penelitian Lubis (2014), Windarti dan Ibrahim (2017) dan Nuriscasani (2017) Produk secara parsial berpengaruh signifikan terhadap Kepuasan Nasabah.

\section{Pengaruh Harga terhadap Kepuasan Nasabah}

Menurut Zeithmal dan Bitner (2003:156), yaitu produk yang mempunyai kualitas yang sama tetapi menetapkan harga yang relatif murah akan memberikan nilai yang lebih tinggi kepada konsumen. Menurut Irwan (2004:37), harga adalah untuk nasabah yang sensitif, biasanya harga murah adalah sumber kepuasan yang penting karena nasabah akan mendapatkan value for money yang tinggi. 
Teori di atas dikuatkan oleh hasil penelitian Lubis (2014), Ningrum (2016), Firdiyansyah (2017), dan Nuriscasani (2017) Harga secara parsial berpengaruh signifikan terhadap Kepuasan Nasabah.

\section{Pengaruh Lokasi terhadap Kepuasan Nasabah}

Menurut Kotler (2008:51), salah satu kunci menuju sukses adalah lokasi, lokasi dimulai dengan memilih komunitas. Menurut Lupiyoadi dan Hamdani (2009:92), lokasi adalah keputusan yang dibuat perusahaan berkaitan dengan di mana operasi dan stafnya akan ditempatkan.

Teori di atas dikuatkan oleh hasil penelitian Huda dan Farida (2014), Wijayaningratri dan Budiyanto (2015), Sari dan Soliha (2018), dan Firdiyansyah (2017) Lokasi secara parsial berpengaruh signifikan terhadap Kepuasan Nasabah.

\section{Kerangka Pemikiran Teoritis}

Kerangka pemikiran teoritis pada penelitian ini terlihat pada Gambar 1.



Gambar 1

Kerangka Pemikiran Teoritis

Sumber: Adaptasi dari berbagai sumber seperti Lupiyoadi (2013), Windarti dan Ibrahim (2017), Manampiring et al. (2016), Ningrum (2016), Tjiptono (2016), yang diolah untuk penelitian ini, 2019.

\section{Hipotesis}

Hipotesis yang diajukan dalam penelitian ini adalah sebagai berikut:

H1 : Diduga variabel kualitas pelayanan, produk, harga, dan lokasi secara simultan berpengaruh signifikan terhadap kepuasan nasabah pada PT Bank Rakyat Indonesia (Persero) Tbk. Unit Ngesrep Semarang.

H2 : Diduga variabel kualitas pelayanan secara parsial berpengaruh signifikan terhadap kepuasan nasabah pada PT Bank Rakyat Indonesia (Persero) Tbk. Unit Ngesrep Semarang.

H3 : Diduga variabel produk secara parsial berpengaruh signifikan terhadap kepuasan nasabah pada PT Bank Rakyat Indonesia (Persero) Tbk. Unit Ngesrep Semarang. 
H4 : Diduga variabel harga secara parsial berpengaruh signifikan terhadap kepuasan nasabah pada PT Bank Rakyat Indonesia (Persero) Tbk. Unit Ngesrep Semarang.

H5 : Diduga variabel lokasi secara parsial berpengaruh signifikan terhadap kepuasan nasabah pada PT Bank Rakyat Indonesia (Persero) Tbk. Unit Ngesrep Semarang.

\section{METODE}

\section{Populasi dan Sampel}

Populasi dalam penelitian ini adalah nasabah PT Bank Rakyat Indonesia (Persero) Tbk. Unit Ngesrep Semarang. Sampel dalam penelitian ini adalah 100 nasabah PT Bank Rakyat Indonesia (Persero) Tbk. Unit Ngesrep Semarang dilakukan dengan menggunakan metode Accidental Sampling merupakan sampling yang memilih sampel dari responden yang paling mudah dijumpai dan diakses. Pengambilan sampel dihitung dengan menggunakan rumus Slovin.

\section{Jenis dan Sumber Data}

Jenis data yang digunakan dalam penelitian ini adalah Data Primer dan Data Sekunder. Data Primer merupakan data yang didapat dari sumber pertama, misalnya dari individual atau perseorangan, seperti hasil wawancara atau pengisian kuesioner yang dilakukan oleh peneliti (Umar, 2003:67). Data Sekunder merupakan data primer yang diolah lebih lanjut, misalnya dalam bentuk seperti tabel, grafik, diagram, dan sebagainya, sehingga lebih informatif jika digunakan oleh pihak lain (Umar, 2003:67).

\section{Metode Pengumpulan Data}

Metode pengumpulan data yang digunakan adalah kuesioner, wawancara, dan observasi. Kuesioner adalah suatu daftar yang berisikan rangkaian pertanyaan mengenai suatu masalah atau bidang yang akan diteliti (Narbuko dan Achmadi, 2008:76). Wawancara adalah proses tanya jawab dalam penelitian yang berlangsung secara lisan dalam mana dua orang atau lebih bertatap muka mendengarkan secara langsung informasi-informasi atau keterangan-keterangan (Narbuko dan Achmadi, 2008:83). Observasi adalah alat pengumpulan data yang dilakukan dengan cara mengamati dan mencatat secara sistematik gejala-gejala yang diselidiki (Narbuko dan Achmadi, 2008:71).

\section{Uji Validitas}

Ghozali (2018:51) mengungkapkan bahwa uji validitas digunakan untuk mengukur sah atau valid tidaknya suatu kuesioner. Suatu kuesioner dikatakan valid jika pertanyaan pada kuesioner mampu untuk mengungkapkan sesuatu yang akan diukur oleh kuesioner tersebut. 


\section{Uji Reliabiltas}

Ghozali (2018:45) mengungkapkan bahwa uji reliabilitas adalah alat untuk mengukur suatu kuesioner yang merupakan indikator dari variabel atau konstruk. Suatu kuesioner dikatakan reliabel atau handal jika jawaban seseorang terhadap pernyataan adalah konsisten atau stabil dari waktu ke waktu.

\section{Metode Analisis Data}

\section{Uji Normalitas}

Ghozali (2018:161) mengungkapkan bahwa uji normalitas bertujuan untuk menguji apakah dalam model regresi variabel pengganggu atau residual mempunyai distribusi normal. Ghozali (2016:163). Ada 2 (dua) cara untuk mendeteksi apakah residual berdistribusi normal atau tidak, yaitu dengan analisis grafik dan uji statistik. Salah satu cara termudah untuk melihat normalitas residual adalah dengan melihat grafik histogram yang membandingkan antara data observasi dengan distribusi yang mendekati distribusi normal. Menurut Ghozali (2018:163), salah satu cara untuk menguji normalitas data dapat menggunakan analisis statistitk, digunakan uji non-parametrik Kolmogorov-Smirnov (K-S). Dalam uji K-S, suatu data akan dikatakan normal apabila mempunyai asymptotic significant lebih dari 0,05.

\section{Uji Multikolonieritas}

Ghozali (2018:107) mengungkapkan bahwa uji multikolonieritas bertujuan untuk menguji apakah model regresi ditemukan adanya korelasi antar variabel independen. Model regresi yang baik seharusnya tidak terjadi korelasi antara variabel independen. Suatu model dikatakan bebas dari multikolonieritas jika nilai tolerance $\geq 0,1$ dan memiliki nilai VIF $\leq 10$.

\section{Uji Autokorelasi}

Ghozali (2016:111) mengungkapkan bahwa uji autokorelasi bertujuan untuk menguji apakah dalam model regresi linier ada korelasi antar kesalahan pengganggu pada periode $\mathrm{t}$ dengan kesalahan pengganggu pada periode t-1 (sebelumnya). Cara untuk mendeteksi ada tidaknya autokorelasi dalam penelitian ini menggunakan Uji Durbin-Watson (DW test).

\section{Uji Heterokedastisitas}

Ghozali (2016:137) mengungkapkan bahwa uji heteroskedastisitas bertujuan untuk menguji apakah dalam model regrasi terjadi ketidaksamaan variance dari residual satu pengamatan ke pangamatan yang lain. Salah satu cara untuk menguji adanya heterokedastisitas adalah Grafik Scatterplot, Uji Glejser, dan Uji Park. 


\section{Model dan Teknik Analisis Data}

\section{Model Analisis Data}

Dalam penulisan penelitian ini menggunakan model analisis regresi linier berganda (Multiple Regression Analysis Model). Analisis regresi pada dasarnya adalah studi mengenai ketergantungan variabel dependen dengan 1 (satu) atau lebih terhadap variabel independen (Ghozali, 2018:95).

$$
Y=a+b_{1} X_{1}+b_{2} X_{2}+b_{3} X_{3}+b_{4} X_{4}+e
$$

Dimana:

$$
\begin{array}{ll}
\mathrm{Y} & =\text { Kepuasan Nasabah. } \\
\alpha & =\text { Konstanta. } \\
\mathrm{X}_{1} & =\text { Kualitas Pelayanan. } \\
\mathrm{X}_{2} & =\text { Produk. } \\
\mathrm{X}_{3} & =\text { Harga. } \\
\mathrm{X}_{4} & =\text { Lokasi. } \\
\mathrm{b}_{1} & =\text { Koefisien regresi dari variabel } \mathrm{X}_{1}, \text { Kualitas Pelayanan. } \\
\mathrm{b}_{2} & =\text { Koefisien regresi dari variabel } \mathrm{X}_{2}, \text { Produk. } \\
\mathrm{b}_{3} & =\text { Koefisien regresi dari variabel } \mathrm{X}_{3}, \text { Harga. } \\
\mathrm{b}_{4} & =\text { Koefisien regresi dari variabel } \mathrm{X}_{4}, \text { Lokasi. } \\
\mathrm{e} & =\text { Error (tingkat kesalahan pengganggu). }
\end{array}
$$

\section{Teknik Analisis Data}

Teknik analisis data dalam penelitian ini menggunakan Uji Statistik F, Uji Koefisien Determinasi (Adjusted $R$ Square), dan Uji Statistik t.

\section{Uji Statistik F}

Ghozali (2016:98), uji statistik F pada dasarnya menunjukkan apakah semua variabel independen atau bebas yang dimasukkan dalam model mempunyai pengaruh secara simultan terhadap variabel dependen/terikat.

\section{Uji Koefisien Determinasi (Adjusted R Square)}

Ghozali (2016:97), Koefisien determinasi (Adjusted $R$ Square) digunakan untuk mengukur seberapa jauh kemampuan model dalam menerangkan variasi variabel dependen. Dalam penelitian ini menggunakan uji Adjusted $R$ Square seperti banyak dianjurkan oleh banyak peneliti karena nilainya tidak dapat naik atau turun apabila terjadi penambahan variabel independen ke dalam model. 


\section{Uji Statistik t}

Ghozali (2016:98), uji statistik t pada dasarnya menunjukkan seberapa jauh pengaruh satu variabel penjelas/independen secara individual dalam menerangkan variasi variabel dependen.

\section{HASIL DAN PEMBAHASAN}

\section{Responden Penelitian}

Sumber data dalam penelitian ini berasal dari jawaban kuesioner yang disebar pada 100 nasabah PT Bank Rakyat Indonesia (Persero) Tbk. Unit Ngesrep Semarang. Adapun karakteristik responden dibagi menjadi 5 yaitu jenis kelamin, usia, Pendidikan, pekerjaan, dan pendapatan sebagai berikut :

Tabel 1

Karakteristik Responden

\begin{tabular}{|c|c|c|}
\hline Jenis Kelamin & Jumlah & Presentase \\
\hline Laki-Laki & 42 & $42 \%$ \\
\hline Perempuan & 58 & $58 \%$ \\
\hline Jumlah & 100 & $100 \%$ \\
\hline Usia & Jumlah & Presentase \\
\hline 17 - 20 Tahun & 25 & $25 \%$ \\
\hline 21 - 30 Tahun & 34 & $34 \%$ \\
\hline 31 - 40 Tahun & 24 & $24 \%$ \\
\hline 41 - 50 Tahun & 14 & $14 \%$ \\
\hline$>50$ Tahun & 3 & $3 \%$ \\
\hline Jumlah & 100 & $100 \%$ \\
\hline Pendidikan & Jumlah & Presentase \\
\hline SD & 5 & $5 \%$ \\
\hline SMP & 8 & $8 \%$ \\
\hline SMA & 45 & $45 \%$ \\
\hline Diploma (D1/D2/D3) & 18 & $18 \%$ \\
\hline Sarjana (S1/S2) & 24 & $24 \%$ \\
\hline Jumlah & 100 & $100 \%$ \\
\hline Pekerjaan & Jumlah & Presentase \\
\hline Pegawai Negeri & 4 & $4 \%$ \\
\hline Wiraswasta & 10 & $10 \%$ \\
\hline Karyawan Swasta & 38 & $38 \%$ \\
\hline Pelajar/Mahasiswa & 42 & $42 \%$ \\
\hline Lainnya & 6 & $6 \%$ \\
\hline Jumlah & 100 & $100 \%$ \\
\hline Pendapatan & Jumlah & Presentase \\
\hline$>$ Rp 1.000.000 & 41 & $41 \%$ \\
\hline Rp 1.000.000 - Rp 2.000.000 & 15 & $15 \%$ \\
\hline $\operatorname{Rp} 2.000 .000$ - Rp 3.000.000 & 23 & $23 \%$ \\
\hline$R p 3.000 .000$ - Rp 4.000.000 & 14 & $14 \%$ \\
\hline$>$ Rp 4.000.000 & 7 & $7 \%$ \\
\hline Jumlah & 100 & $100 \%$ \\
\hline
\end{tabular}

Sumber: Data Primer yang diolah dengan SPSS 25, 2019. 
keunis Majalah Ilmiah - ISSN No 2302-9315 Vol. 7 No 2 Thn VII Juli 2019

\section{Uji Validitas}

Hasil dari Uji Validitas pada penelitian ini dapat dilihat pada Tabel 2.

Tabel 2

Hasil Uji Validitas

\begin{tabular}{|c|c|c|c|c|}
\hline Variabel & Indikator & rhitung & $\mathbf{r}_{\text {tabel }}$ & Keterangan \\
\hline \multirow{5}{*}{$\begin{array}{l}\text { Kualitas } \\
\text { Pelayanan }\end{array}$} & $\mathbf{X}_{1.1}$ & 0,676 & \multirow{5}{*}{0,1966} & Valid \\
\hline & $\mathbf{X}_{1.2}$ & 0,782 & & Valid \\
\hline & $\mathbf{X}_{1.3}$ & 0,752 & & Valid \\
\hline & $\mathbf{X}_{1.4}$ & 0,666 & & Valid \\
\hline & $\mathbf{X}_{1.5}$ & 0,733 & & Valid \\
\hline \multirow{8}{*}{ Produk } & $\mathbf{X}_{2.1}$ & 0,693 & \multirow{8}{*}{0,1966} & Valid \\
\hline & $\mathbf{X}_{2.2}$ & 0,693 & & Valid \\
\hline & $\mathbf{X}_{2.3}$ & 0,683 & & Valid \\
\hline & $\mathbf{X}_{2.4}$ & 0,668 & & Valid \\
\hline & $\mathbf{X}_{2.5}$ & 0,662 & & Valid \\
\hline & $\mathrm{X}_{2.6}$ & 0,714 & & Valid \\
\hline & $\mathbf{X}_{2.7}$ & 0,706 & & Valid \\
\hline & $\mathrm{X}_{2.8}$ & 0,672 & & Valid \\
\hline \multirow{3}{*}{ Harga } & $\mathbf{X}_{3.1}$ & 0,839 & \multirow{3}{*}{0,1966} & Valid \\
\hline & $\mathbf{X}_{3.2}$ & 0,850 & & Valid \\
\hline & $\mathbf{X}_{3.3}$ & 0,832 & & Valid \\
\hline \multirow{3}{*}{ Lokasi } & $\mathbf{X}_{4.1}$ & 0,844 & \multirow{3}{*}{0,1966} & Valid \\
\hline & $\mathbf{X}_{4.2}$ & 0,862 & & Valid \\
\hline & $\mathbf{X}_{4.3}$ & $\mathbf{0 , 8 3 9}$ & & Valid \\
\hline \multirow{5}{*}{$\begin{array}{c}\text { Kepuasan } \\
\text { Nasabah }\end{array}$} & $Y_{1.1}$ & 0,823 & \multirow{5}{*}{0,1966} & Valid \\
\hline & $Y_{1.2}$ & 0,739 & & Valid \\
\hline & $\mathbf{Y}_{1.3}$ & 0,686 & & Valid \\
\hline & $Y_{1.4}$ & 0,681 & & Valid \\
\hline & $\mathbf{Y}_{1.5}$ & 0,758 & & Valid \\
\hline
\end{tabular}

Sumber: Data Primer yang diolah dengan SPSS 25, 2019.

Berdasarkan Tabel 2 dapat diketahui bahwa seluruh item pertanyaan mengenai dari seluruh variabel 24 item, mempunyai $r_{\text {hitung }}>r_{\text {tabel, }}$ dan sesuai dengan ketentuan yang telah ditetapkan, maka hal ini berarti bahwa seluruh item pertanyaan valid dan dapat digunakan dalam penelitian.

\section{Uji Reliabilitas}

Hasil dari UjI Reliabilitas pada penelitian ini dapat dilihat pada Tabel 3.

Tabel 3

Hasil Uji Reliabilitas

\begin{tabular}{cccc}
\hline Variabel & Cronbach's Alpha & Standar Minimum & Keterangan \\
\hline Kualitas Pelayanan & $\mathbf{0 , 7 7 1}$ & & Reliabel \\
Produk & $\mathbf{0 , 8 3 9}$ & & Reliabel \\
Harga & $\mathbf{0 , 7 9 1}$ & $\mathbf{0 , 7 0}$ & Reliabel \\
Lokasi & $\mathbf{0 , 8 0 5}$ & & Reliabel \\
Kepuasan Nasabah & $\mathbf{0 , 7 9 1}$ & & Reliabel \\
\hline
\end{tabular}

Sumber: Data Primer yang diolah dengan SPSS 25, 2019. 
Berdasarkan Tabel 3 dapat diketahui bahwa seluruh item pertanyaan mengenai dari seluruh variabel 24 item, mempunyai $r_{\text {hitung }}>r_{\text {tabel, }}$ dan sesuai dengan ketentuan yang telah ditetapkan, maka hal ini berarti bahwa seluruh item pertanyaan valid dan dapat digunakan dalam penelitian.

\section{Uji Normalitas}

Hasil dari Uji Normalitas pada penelitian ini dapat dilihat pada Gambar 2., Gambar 3. dan Tabel 4.

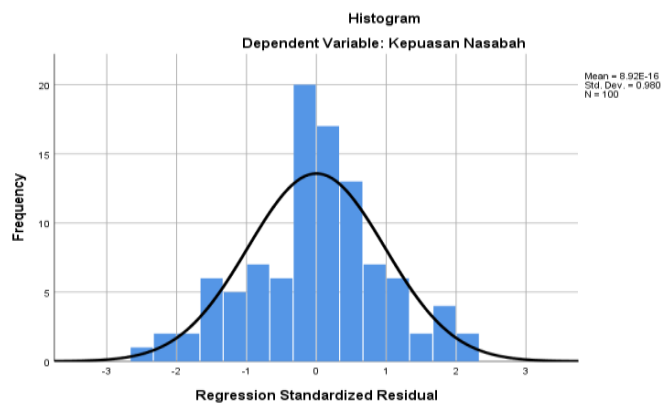

Gambar 2

Grafik Histogram

Sumber: Data Primer yang diolah dengan SPSS 25, 2019.

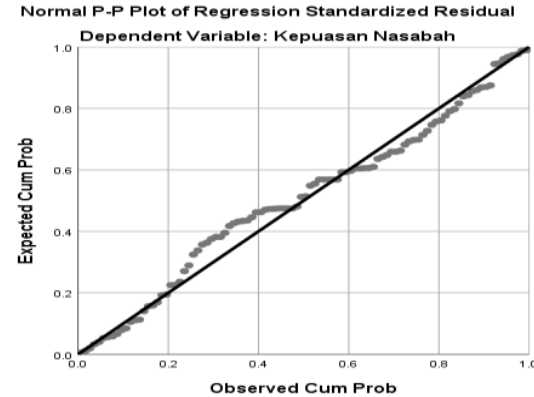

Gambar 3

Normal Probability Plot

Sumber: Data Primer yang diolah dengan SPSS 25, 2019.

Berdasarkan pada Gambar 2 terlihat bahwa histogram menunjukkan distribusi normal, dan pada Gambar 3 terlihat bahwa data menyebar di sekitar garis diagonal dan mengikuti arah garis diagonal, maka model garis regresi memenuhi asumsi normalitas. 
Tabel 4

Hasil Uji Normalitas Kolmogorov - Smirnov

One-Sample Kolmogorov-Smirnov Test

\begin{tabular}{|c|c|c|}
\hline & & $\begin{array}{l}\text { Unstandardized } \\
\text { Residual }\end{array}$ \\
\hline$N$ & & 100 \\
\hline \multirow[t]{2}{*}{ Normal Parameters ${ }^{a, b}$} & Mean & .0000000 \\
\hline & $\begin{array}{l}\text { Std. } \\
\text { Deviation }\end{array}$ & 1.01513226 \\
\hline Extreme & Absolute & .086 \\
\hline \multirow[t]{2}{*}{ Differences } & Positive & .058 \\
\hline & Negative & -.086 \\
\hline Test Statistic & & .086 \\
\hline Asymp. Sig. (2-tailed) & & $.067^{\mathrm{c}}$ \\
\hline
\end{tabular}

Sumber: Data Primer yang diolah dengan SPSS 25, 2019.

Berdasarkan Tabel 4 dapat diketahui bahwa nilai signifikansi (Asymp.Sig.(2-tailed)) sebesar 0.67. Karena signifikansi lebih besar dari 0.05 maka variabel penelitian memiliki distribusi data yang normal (Ghozali, 2016:163).

\section{Uji Multikolonieritas}

Hasil dari Uji multikolonieritas dapat dilihat pada Tabel 5.

Tabel 5

Uji Multikolonieritas

\begin{tabular}{|c|c|c|c|}
\hline \multicolumn{4}{|c|}{ Coefficients $^{a}$} \\
\hline \multirow{2}{*}{\multicolumn{2}{|c|}{ Model }} & \multicolumn{2}{|c|}{ Collinierity Statistics } \\
\hline & & Tolerance & VIF \\
\hline \multirow[t]{5}{*}{1} & (Constant) & & \\
\hline & Kualitas Pelayanan & .524 & 1.910 \\
\hline & Produk & .698 & 1.434 \\
\hline & Harga & .749 & 1.336 \\
\hline & Lokasi & .731 & 1.367 \\
\hline
\end{tabular}

Sumber: Data Primer yang diolah dengan SPSS 25, 2019.

Berdasarkan Tabel 5 dapat diketahui bahwa nilai Tolerance ketiga variabel bernilai lebih dari 0.10 dan nilai Variance Inflation Factor (VIF) bernilai kurang dari 10, maka dapat diambil kesimpulan bahwa model regresi yang melibatkan 4(empat) variabel bebas dengan satu variabel terikat yaitu kepuasan nasabah (Y) dinyatakan tidak mengandung masalah multikolonieritas (Ghozali, 2016:107).

\section{Uji Heterokedastisitas}

Hasil dari Uji Heteroskedastisitas dapat dilihat pada Gambar 4, Tabel 6, dan Tabel 7. 


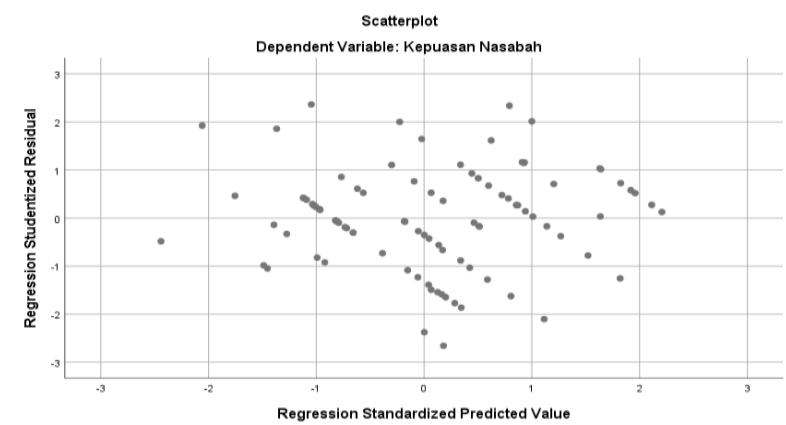

Gambar 4

Uji Scatterplot

Sumber: Data Primer yang diolah dengan SPSS 25, 2019.

Tabel 6

Uji Park

\begin{tabular}{|c|c|c|c|c|c|c|}
\hline \multicolumn{7}{|c|}{ Coefficients $^{a}$} \\
\hline \multirow{2}{*}{\multicolumn{2}{|c|}{ Model }} & \multicolumn{2}{|c|}{$\begin{array}{c}\text { Unstandardized } \\
\text { Coefficients }\end{array}$} & $\begin{array}{c}\text { Standardized } \\
\text { Coefficients }\end{array}$ & \multirow[t]{2}{*}{$\mathrm{t}$} & \multirow[t]{2}{*}{ Sig. } \\
\hline & & $B$ & Std. Error & Beta & & \\
\hline \multirow[t]{5}{*}{1} & (Constant) & -4.868 & 2.283 & & -2.132 & .036 \\
\hline & $\begin{array}{l}\text { Kualitas } \\
\text { Pelayanan }\end{array}$ & -.045 & .149 & -.042 & -.299 & .766 \\
\hline & Produk & .081 & .091 & .107 & .890 & .376 \\
\hline & Harga & .225 & .159 & .165 & 1.421 & .159 \\
\hline & Lokasi & -.021 & .181 & -.014 & -.115 & .908 \\
\hline
\end{tabular}

Sumber: Data Primer yang diolah dengan SPSS 25, 2019.

Tabel 7

Uji Glejser

\begin{tabular}{|c|c|c|c|c|c|c|}
\hline \multicolumn{7}{|c|}{ Coefficients $^{a}$} \\
\hline \multirow{2}{*}{\multicolumn{2}{|c|}{ Model }} & \multicolumn{2}{|c|}{$\begin{array}{l}\text { Unstandardized } \\
\text { Coefficients }\end{array}$} & \multirow{2}{*}{$\begin{array}{c}\begin{array}{c}\text { Standardized } \\
\text { Coefficients }\end{array} \\
\text { Beta }\end{array}$} & \multirow[t]{2}{*}{$\mathrm{t}$} & \multirow[t]{2}{*}{ Sig } \\
\hline & & $B$ & Std. Error & & & \\
\hline \multirow[t]{5}{*}{1} & (Constant) & -.232 & .693 & & -.335 & .738 \\
\hline & $\begin{array}{l}\text { Kualitas } \\
\text { Pelayanan }\end{array}$ & -.012 & .045 & -.037 & -.265 & .792 \\
\hline & Produk & .023 & .028 & .100 & .825 & .412 \\
\hline & Harga & .063 & .048 & .152 & 1.304 & .195 \\
\hline & Lokasi & -.002 & .055 & -.003 & -.029 & .977 \\
\hline
\end{tabular}

Sumber: Data Primer yang diolah dengan SPSS 25, 2019.

Berdasarkan Tabel 4 dapat diketahui bahwa nilai signifikansi ketiga variabel lebih dari 0.05, maka dapat diambil kesimpulan, bahwa model regresi yang melibatkan 3 (tiga) variabel bebas dengan satu variabel terikat yaitu penyaluran kredit (Y) dinyatakan tidak mengandung masalah heteroskedastisitas (Ghozali, 2016:137). 


\section{Uji Autokorelasi}

Hasil dari Uji Autokorelasi dapat dilihat pada Tabel 8.

Tabel 8

Uji Autokorelasi

\begin{tabular}{|c|c|c|r|r|r|}
\hline \multicolumn{6}{|c|}{ Model Summary $^{b}$} \\
\hline Model & $R$ & $\begin{array}{c}R \\
\text { Square }\end{array}$ & $\begin{array}{c}\text { Adjusted } R \\
\text { Square }\end{array}$ & $\begin{array}{c}\text { Std. Error of } \\
\text { the Estimate }\end{array}$ & $\begin{array}{c}\text { Durbin- } \\
\text { Watson }\end{array}$ \\
\hline 1 &, $843^{\mathrm{a}}$ &, 711 &, 699 & 1,036 & 2,073 \\
\hline
\end{tabular}

a. Predictors : (Constant), Lokasi, Harga, Produk, Kualitas Pelayanan

b. Dependent Variable: Kepuasan Nasabah

\section{Sumber: Data Primer yang diolah dengan SPSS 25, 2019.}

Berdasarkan model summary pada Tabel 8. menunjukkan bahwa nilai Durbin-Watson $(D W)$ sebesar 2,073. Nilai ini akan dibandingkan dengan nilai tabel, yang mana jumlah sampel $(\mathrm{n})=100$ dan jumlah variabel dependen $(\mathrm{k})=4$, maka di tabel Durbin-Watson akan didapat du $=1,758$. Oleh karena nilai Durbin-Watson $(D W)$ lebih dari batas atas (du) sebesar 1,758 dan kurang dari 4-1,7582 (4-du) atau dengan kata lain 1,758<2,073<2,242, maka dapat disimpulkan bahwa tidak ada korelasi positif dan negatif atau tidak terdapat autokorelasi pada model regresi ini.

\section{Model Analisis Data}

Penentuan pengaruh variabel independen yaitu Kualitas Pelayanan, Produk, Harga, dan Lokasi terhadap Kepuasan Nasabah sebagai variabel dependen, peneliti menggunakan SPSS 25 dapat dilihat pada Tabel 9.

Tabel 9

Hasil Uji Analisis Regresi Linier Berganda

\begin{tabular}{|c|c|c|c|}
\hline \multicolumn{2}{|c|}{ Model } & \multicolumn{2}{|c|}{ Unstandardized Coefficients } \\
\hline & & $B$ & Std. Error \\
\hline \multirow[t]{5}{*}{1} & (Constant) & .644 & 1.080 \\
\hline & Kualitas Pelayanan & .309 & .071 \\
\hline & Produk & .150 & .043 \\
\hline & Harga & .245 & .075 \\
\hline & Lokasi & .443 & .086 \\
\hline
\end{tabular}

Sumber: Data Primer yang diolah dengan SPSS 25, 2019.

Berdasarkan Tabel 9 dapat disusun persamaan regresi linier berganda sebagai berikut:

Kepuasan Nasabah = 0,644 + 0,309 Kualitas Pelayanan + 0,150 Produk + 0,245 Harga $+0,443$ Lokasi $+e$ 
Berdasarkan persamaan regresi di atas, dapat di interprestasikan sebagai berikut:

\section{Konstanta $(\mathbf{a})=0,644$}

Konstanta sebesar 0,644 menunjukkan bahwa jika variabel independen yaitu kualitas pelayanan $\left(\mathrm{X}_{1}\right)$, produk $\left(\mathrm{X}_{2}\right)$, harga $\left(\mathrm{X}_{3}\right)$, dan lokasi $\left(\mathrm{X}_{4}\right)$ bernilai 0 (nol), maka variabel kepuasan nasabah bernilai positif 0,644.

\section{Koefisien Kualitas Pelayanan $\left(b_{1}\right)=0,309$}

Hal ini menunjukkan bahwa variabel kualitas pelayanan berpengaruh positif terhadap kepuasan nasabah pada PT Bank Rakyat Indonesia (Persero) Tbk. Unit Ngesrep Semarang. Setiap terjadi kenaikan variabel kualitas pelayanan sebesar 1 (satu) satuan, maka kepuasan nasabah pada PT Bank Rakyat Indonesia (Persero) Tbk. Unit Ngesrep Semarang akan meningkat sebesar 0,309 menjadi 0,953 , dengan asumsi variabel produk $\left(\mathrm{X}_{2}\right)$, harga $\left(\mathrm{X}_{3}\right)$, dan lokasi $\left(\mathrm{X}_{4}\right)$ bernilai 0 (nol).

\section{Koefisien Produk $\left(\mathbf{b}_{2}\right)=0,150$}

Hal ini menunjukkan bahwa variabel produk berpengaruh positif terhadap kepuasan nasabah pada PT Bank Rakyat Indonesia (Persero) Tbk. Unit Ngesrep Semarang. Setiap terjadi kenaikan variabel produk sebesar 1 (satu) satuan, maka kepuasan nasabah pada PT Bank Rakyat Indonesia (Persero) Tbk. Unit Ngesrep Semarang akan meningkat sebesar 0,150 menjadi 0,794 , dengan asumsi variabel kualitas pelayanan $\left(\mathrm{X}_{1}\right)$, harga $\left(\mathrm{X}_{3}\right)$, dan lokasi $\left(\mathrm{X}_{4}\right)$ bernilai 0 (nol).

\section{Koefisien Harga $\left(b_{3}\right)=0,245$}

Hal ini menunjukkan bahwa variabel harga berpengaruh positif terhadap kepuasan nasabah pada PT Bank Rakyat Indonesia (Persero) Tbk. Unit Ngesrep Semarang. Setiap terjadi kenaikan variabel harga sebesar 1 (satu) satuan, maka kepuasan nasabah pada PT Bank Rakyat Indonesia (Persero) Tbk. Unit Ngesrep Semarang akan meningkat sebesar 0,245 menjadi 0,899 , dengan asumsi variabel kualitas pelayanan $\left(X_{1}\right)$, produk $\left(X_{2}\right)$, dan lokasi $\left(\mathrm{X}_{4}\right)$ bernilai $0(\mathrm{nol})$.

\section{Koefisien Lokasi $\left(b_{4}\right)=0,443$}

Hal ini menunjukkan bahwa variabel lokasi berpengaruh positif terhadap kepuasan nasabah pada PT Bank Rakyat Indonesia (Persero) Tbk. Unit Ngesrep Semarang. Setiap terjadi kenaikan variabel lokasi sebesar 1 (satu) satuan, maka kepuasan nasabah pada PT Bank Rakyat Indonesia (Persero) Tbk. Unit Ngesrep Semarang akan meningkat sebesar 0,443 menjadi 1,976 dengan asumsi variabel kualitas pelayanan $\left(\mathrm{X}_{1}\right)$, produk $\left(\mathrm{X}_{2}\right)$, dan harga $\left(\mathrm{X}_{3}\right)$ bernilai 0 (nol). 


\section{Teknik Analisis Data}

\section{Uji Statistik F}

Hasil dari Uji Statistik F dapat dilihat pada Tabel 10.

Tabel 10

Uji Statistik F

\begin{tabular}{|l|l|r|r|r|r|r|}
\hline \multicolumn{7}{|l|}{ ANOVA $^{\text {a }}$} \\
\hline \multirow{2}{|l|}{ Model } & $\begin{array}{l}\text { Sum of } \\
\text { Square }\end{array}$ & $d f$ & $\begin{array}{l}\text { Mean } \\
\text { Squre }\end{array}$ & F & Sig, \\
\cline { 2 - 7 } & Regression & 251.021 & 4 & 62.755 & 58.438 & $.000^{\text {b }}$ \\
\cline { 2 - 7 } & Residual & 102.019 & 95 & 1.074 & & \\
\cline { 2 - 7 } & Total & 353.040 & 99 & & & \\
\hline
\end{tabular}

a. Dependent Variable: Kepuasan Nasabah

b. Predictors: (Constant), Lokasi, Harga, Produk, Kualitas Pelayanan

\section{Sumber: Data Primer yang diolah dengan SPSS 25, 2019.}

Berdasarkan Tabel 10. dihasilkan $F_{\text {hitung }}=58,438>F_{\text {tabel }}=2,70$ atau signifikansi $=0,000$ $<0,05$, yang berarti terdapat pengaruh yang signifikan antara variabel kualitas pelayanan, produk, harga, dan lokasi secara simultan terhadap kepuasan nasabah. Dengan demikian hipotesis 1 (satu) yang menyatakan "Diduga variabel kualitas pelayanan, produk, harga, dan lokasi secara simultan berpengaruh signifikan terhadap kepuasan nasabah pada PT Bank Rakyat Indonesia (Persero) Tbk. Unit Ngesrep Semarang” dinyatakan diterima.

\section{Uji Koefisien Determinasi (Adjusted R Square)}

Hasil dari Uji Koefisien Determinasi (Adjusted R Square) dapat dilihat pada Tabel 11.

\section{Tabel 11}

Uji Koefisien Determinasi $\left(\mathbf{R}^{2}\right)$

\begin{tabular}{|c|c|c|c|c|c|}
\hline \multicolumn{6}{|c|}{ Model Summary ${ }^{b}$} \\
\hline Model & $\mathrm{R}$ & $\begin{array}{c}R \\
\text { Square }\end{array}$ & $\begin{array}{l}\text { Adjusted } R \\
\text { Square }\end{array}$ & $\begin{array}{l}\text { Std. Error of } \\
\text { the Estimate }\end{array}$ & $\begin{array}{l}\text { Durbin- } \\
\text { Watson }\end{array}$ \\
\hline 1 &, $843^{\mathrm{a}}$ & ,711 & 699 & 1,036 & 2,073 \\
\hline \multicolumn{6}{|c|}{ a. Predictors : (Constant), Lokasi, Harga, Produk, Kualitas Pelayanan } \\
\hline b. $\quad$ Def & - & 2 & Nasabah & & \\
\hline
\end{tabular}

\section{Sumber: Data Primer yang diolah dengan SPSS 25, 2019.}

Berdasarkan hasil uji koefisien determinasi pada Tabel 11. dihasilkan nilai Adjusted $R$ Square sebesar 0,699 atau 69,9\%. Artinya variabel kualitas pelayanan, produk, harga, dan lokasi memberikan kontribusi pengaruh terhadap kepuasan nasabah sebesar 69,9\%. Sedangkan sisanya sebesar 30,1\% dipengaruhi oleh variabel lain yang tidak diteliti dalam penelitian ini. 


\section{Uji Statistik t}

Hasil dari Uji Statistik t dapat dilihat pada Tabel 12.

\section{Tabel 12}

Uji Statistik t

\begin{tabular}{|l|r|r|r|r|r|}
\hline \multirow{2}{*}{ Model } & \multicolumn{2}{|c|}{$\begin{array}{c}\text { Unstandardized } \\
\text { Coefficients. }\end{array}$} & $\begin{array}{c}\text { Standardized } \\
\text { Coefficients }\end{array}$ & & \\
\cline { 2 - 5 } & \multicolumn{1}{|c|}{ B } & Std. Error & \multicolumn{1}{|c|}{ Beta } & \multicolumn{1}{c|}{ S } & \multicolumn{1}{c|}{ Sig. } \\
\hline Kualitas Pelayanan & .644 & 1.080 & & .596 & .552 \\
Produk & .309 & .071 & .333 & 4.373 & .000 \\
Harga & .150 & .043 & .230 & 3.489 & .001 \\
Lokasi & .245 & .075 & .209 & 3.272 & .001 \\
\cline { 1 - 3 } a. Dependent Variabel: Kepuasan Nasabah & .443 & .086 & .334 & 5.175 & .000 \\
\hline
\end{tabular}

\section{Sumber: Data Primer yang diolah dengan SPSS 25, 2019.}

Berdasarkan Tabel 12 dapat diketahui bahwa:

1. $\mathrm{t}_{\text {hitung }}$ untuk variabel kualitas pelayanan $=4,373>\mathrm{t}_{\text {tabel }}=1,985$ atau signifikansi $=0,000<$ 0,05, yang berarti terdapat pengaruh yang signifikan antara kualitas pelayanan secara parsial terhadap kepuasan nasabah. Dengan demikian hipotesis 2 (dua) yang menyatakan "Diduga variabel kualitas pelayanan secara parsial berpengaruh signifikan terhadap kepuasan nasabah pada PT Bank Rakyat Indonesia (Persero) Tbk. Unit Ngesrep Semarang”, dinyatakan diterima.

2. $\mathrm{t}_{\text {hitung }}$ untuk variabel produk $=3,489>\mathrm{t}_{\text {tabel }}=1,985$ atau signifikansi $=0,001<0,05$, yang berarti terdapat pengaruh yang signifikan antara produk secara parsial terhadap kepuasan nasabah. Dengan demikian hipotesis 3 (tiga) yang menyatakan "Diduga variabel produk secara parsial berpengaruh signifikan terhadap kepuasan nasabah pada PT Bank Rakyat Indonesia (Persero) Tbk. Unit Ngesrep Semarang", dinyatakan diterima.

3. $\mathrm{t}_{\text {hitung }}$ untuk variabel harga $=3,272>\mathrm{t}_{\text {tabel }}=1,985$ atau signifikansi $=0,001<0,05$, yang berarti terdapat pengaruh yang signifikan antara harga secara parsial terhadap kepuasan nasabah. Dengan demikian hipotesis 4 (empat) yang menyatakan "Diduga variabel harga secara parsial berpengaruh signifikan terhadap kepuasan nasabah pada PT Bank Rakyat Indonesia (Persero) Tbk. Unit Ngesrep Semarang", dinyatakan diterima.

4. thitung untuk variabel lokasi $=5,175>\mathrm{t}_{\text {tabel }}=1,985$ atau signifikansi $=0,000<0,05$, yang berarti terdapat pengaruh yang signifikan antara lokasi secara parsial terhadap kepuasan nasabah. Dengan demikian hipotesis 5 (lima) yang menyatakan "Diduga variabel lokasi secara parsial berpengaruh signifikan terhadap kepuasan nasabah pada PT Bank Rakyat Indonesia (Persero) Tbk. Unit Ngesrep Semarang”, dinyatakan diterima. 


\section{Pembahasan Hasil Uji t}

\section{Pengaruh variabel Kualitas Pelayanan terhadap Kepuasan Nasabah}

Berdasarkan Tabel 12 diperoleh hasil bahwa nilai thitung untuk variabel Kualitas Pelayanan $=4,373>\mathrm{t}_{\text {tabel }}=1,985$ atau signifikansi $=0.000<0.05$ dengan arah koefisien regresi positif, sehingga Kualitas Pelayanan secara parsial berpengaruh positif dan signifikan terhadap kepuasan nasabah.

Dilihat dari aspek arah pengaruh menunjukkan bahwa kualitas pelayanan berpengaruh positif terhadap kualitas pelayanan, artinya semakin baik kualitas pelayanan yang diberikan bank kepada nasabah akan cenderung meningkatkan kepuasan nasabah pada PT Bank Rakyat Indonesia (Persero) Tbk. Unit Ngesrep Semarang.

Hasil penelitian ini mendukung penelitian terdahulu yang dilakukan oleh Ghozali (2014), Wijayaningratri dan Budiyanto (2015), Ningrum (2015), serta Nuriscasani (2017), yang menyatakan bahwa kualitas pelayanan berpengaruh signifikan terhadap kepuasan nasabah.

\section{Pengaruh variabel Produk terhadap Kepuasan Nasabah}

Berdasarkan Tabel 12 diperoleh hasil bahwa nilai thitung untuk variabel Produk = 3,489 > $\mathrm{t}_{\text {tabel }}=1,985$ atau signifikansi $=0.001>0.05$ dengan arah koefisien regresi positif, sehingga Produk secara parsial berpengaruh positif dan signifikan terhadap kepuasan nasabah.

Dilihat dari aspek arah pengaruh menunjukkan bahwa produk berpengaruh positif terhadap kepuasan nasabah, artinya semakin baik produk yang ditawarkan bank kepada nasabah akan cenderung meningkatkan kepuasan nasabah pada PT Bank Rakyat Indonesia (Persero) Tbk. Unit Ngesrep Semarang.

Hasil penelitian ini mendukung penelitian terdahulu yang dilakukan oleh Lubis (2014), Windarti dan Ibrahim (2017), serta Nuriscasani (2017), yang menyatakan bahwa produk berpengaruh signifikan terhadap kepuasan nasabah.

\section{Pengaruh variabel Harga terhadap Kepuasan Nasabah}

Berdasarkan Tabel 12 diperoleh hasil bahwa nilai thitung untuk variabel Harga = 3,272 > $\mathrm{t}_{\text {tabel }}=1,985$ atau signfikansi $=0.001>0.05$ dengan arah koefisien regresi positif, sehingga Harga secara parsial berpengaruh positif dan signifikan terhadap kepuasan nasabah.

Dilihat dari aspek arah pengaruh menunjukkan bahwa harga berpengaruh positif terhadap kepuasan nasabah, artinya semakin kompetitif harga yang ditawarkan bank akan cenderung meningkatkan kepuasan nasabah pada PT Bank Rakyat Indonesia (Persero) Tbk. Unit Ngesrep Semarang. 
Hasil penelitian ini mendukung penelitian terdahulu yang dilakukan oleh Lubis (2014), Ningrum (2016), Firdiyansyah (2017), serta Nuriscasani (2017), yang menyatakan bahwa harga berpengaruh signifikan terhadap kepuasan nasabah.

\section{Pengaruh variabel Lokasi terhadap Kepuasan Nasabah}

Berdasarkan Tabel 12 diperoleh hasil bahwa nilai thitung untuk variabel Lokasi $=5,175>$ $\mathrm{t}_{\text {tabel }}=1,985$ atau signfikansi $=0.000>0.05$ dengan arah koefisien regresi positif, sehingga Harga secara parsial berpengaruh positif dan signifikan terhadap kepuasan nasabah.

Dilihat dari aspek arah pengaruh menunjukkan bahwa lokasi berpengaruh positif terhadap kepuasan nasabah, artinya semakin baik lokasi dan mudah dijangkau oleh nasabah akan cenderung meningkatkan kepuasan nasabah pada PT Bank Rakyat Indonesia (Persero) Tbk. Unit Ngesrep Semarang.

Hasil penelitian ini mendukung penelitian terdahulu yang dilakukan oleh Huda dan Farida (2014), Wijayaningratri dan Budiyono (2015), Firdiyansyah (2017), serta Sari dan Soliha (2018), yang menyatakan bahwa lokasi berpengaruh signifikan terhadap kepuasan nasabah.

\section{PENUTUP}

\section{Kesimpulan}

Berdasarkan pengujian hipotesis dan pembahasan sebelumnya, maka diperoleh kesimpulan sebagai berikut:

1. Variabel-variabel kepuasan nasabah yang meliputi kualitas pelayanan, produk, harga, dan lokasi secara simultan berpengaruh signifikan terhadap kepuasan nasabah pada PT Bank Rakyat Indonesia (Persero) Tbk. Unit Ngesrep Semarang dengan $F_{\text {hitung }}$ sebesar 58,438 lebih besar dari $F_{\text {tabel }}$ sebesar 2,70 dan signifikansi pada 0,000 (di bawah 0,05).

2. Variabel kualitas pelayanan secara parsial berpengaruh positif dan signifikan terhadap kepuasan nasabah pada PT Bank Rakyat Indonesia (Persero) Tbk. Unit Ngesrep Semarang dengan thitung sebesar 4,373 lebih besar dari tabel sebesar 1,985 dan signifikansi pada 0,000 (di bawah 0,05).

3. Variabel produk secara parsial berpengaruh positif dan signifikan terhadap kepuasan nasabah pada PT Bank Rakyat Indonesia (Persero) Tbk. Unit Ngesrep Semarang dengan $t_{\text {hitung }}$ sebesar 3,489 lebih besar dari tabel sebesar 1,985 dan signifikansi pada 0,001 (di bawah $0,05)$. 
4. Variabel harga secara parsial berpengaruh positif dan signifikan terhadap kepuasan nasabah pada PT Bank Rakyat Indonesia (Persero) Tbk. Unit Ngesrep Semarang dengan $t_{\text {hitung }}$ sebesar 3,272 lebih besar dari $t_{\text {tabel }}$ sebesar 1,985 dan signifikansi pada 0,001 (di bawah $0,05)$.

5. Variabel lokasi secara parsial berpengaruh positif dan signifikan terhadap kepuasan nasabah pada PT Bank Rakyat Indonesia (Persero) Tbk. Unit Ngesrep Semarang dengan $t_{\text {hitung }}$ sebesar 5,175 lebih besar dari tabel sebesar 1,985 dan signifikansi pada 0,000 (di bawah $0,05)$.

\section{Keterbatasan Penelitian}

1. Sehubungan dengan adanya kecenderungan keterkaitan antar variabel yang menyebabkan nilai Adjusted $R$ Square rendah, sehingga pengaruh antara kualitas pelayanan, produk, harga, dan lokasi terhadap kepuasan nasabah hanya sebesar 69,9\%, padahal ketika uji $\mathrm{F}$ signifikan idealnya Adjusted R Square mendekati $100 \%$.

2. Objek penelitian ini terbatas pada PT Bank Rakyat Indonesia (Persero) Tbk. Unit Ngesrep Semarang dengan kriteria sampel tertentu.

\section{Saran}

Peneliti memberikan beberapa saran untuk penelitian selanjutnya dalam topic yang sama sebagai berikut:

1. Penelitian mendatang diharapkan menambah variabel independen lain agar diperoleh temuan baru mengenai faktor-faktor yang dapat memengaruhi kepuasan nasabah seperti promosi atau tingkat suku bunga dan menguji kepuasan nasabah lebih spesifik misalnya, kepuasan nasabah simpanan atau nasabah kredit.

2. Penelitian mendatang diharapkan menggunakan objek lebih dari satu bank agar hasilnya dapat dibandingkan seberapa besar pengaruh kualitas pelayanan, produk, harga, dan lokasi terhadap kepuasan nasabah dari kedua bank tersebut.

\section{DAFTAR PUSTAKA}

Firdiyansyah, Indra. 2017. Pengaruh Kualitas Pelayanan, Harga, dan Lokasi Terhadap Kepuasan Pelanggan pada Warung Gubrak Kepri Mall Kota Batam. Ejournal Stiegalileo. Volume 1. Nomor 1.

Ghozali, Imam. 2018. Aplikasi Analisis Multivariate Dengan Program IBM SPSS 25. Semarang: Badan Penerbit Universitas Diponegoro. 
Ghozali, Moch. 2014. Pengaruh Kualitas Pelayanan Dan Harga Terhadap Kepuasan Pelanggan Pada Expedisi di Surabaya. Jurnal Ilmu dan Riset Manajemen. Volume 3. Nomor 3.

Huda, Ahmad Samsul dan Ida Farida. 2014. Pengaruh Pelayanan, Promosi dan Lokasi

Terhadap Kepuasan Konsumen Toko Joko Elektronik di Pati. UDiNus Repository.

Kasmir. 2012. Dasar-Dasar Perbankan. Jakarta: PT Raja Grafindo Persada.

Kotler, Philip, dan Gary Armstrong. 2008. Prinsip-Prinsip Pemasaran. Jakarta: Erlangga.

Lubis, M. Saleh. 2014. Pengaruh Produk dan Harga Terhadap Kepuasan Pelanggan Atas

Produk Roundap Di Simpang Empat. E-Journal Apresiasi Ekonomi. Volume 2. Nomor 3.

Lupiyoadi, Rambat dan Hamdani A. 2009. Manajemen Pemasaran Jasa. Jakarta: Salemba Empat.

Lupiyoadi, Rambat. 2013. Manajemen Pemasaran Jasa. Jakarta: Salemba Empat.

Manampiring, Andreas S. Willem J. A. F. Tumbuan, dan Rudy S. Wenas. 2016. Analisis

Produk, Harga, Lokasi, Promosi Terhadap Kepuasan Konsumen Pada Kartu Kredit PT

Bank Mandiri, Tbk Manado. Jurnal EMBA. Volume 4. Nomor 2.

Markoni. 2011. Pengaruh Dimensi Kualitas Produk Terhadap Kepuasan Nasabah Perbankan.

Jurnal Ilmiah Orasi Bisnis (ISSN: 2085-1375). Volume 1. Nomor 1.

Narbuko, Cholid dan Abu Achmadi. 2008. Metodologi Penelitian. Jakarta: PT Bumi Aksara.

Ratnasari, Ririn Tri. dan Mastuti, H Aksa. 2011. Manajemen Pemasaran Jasa. Bogor: Ghalia Indonesia.

Sari, Lidia Kurnia dan Euis Soliha. 2018. Kualitas Layanan, Persepsi Tingkat Suku Bunga dan

Lokasi Terhadap Kepuasan Nasabah. Proceeding SENDI_U.

Tjiptono, Fandy. 2002. Strategi Pemasaran Jasa. Yogyakarta: ANDI.

Tjiptono, Fandy. 2011. Pemasaran Jasa. Malang: Banyumedia.

Tjiptono, Fandy. 2012. Prinsip-Prinsip Total Quality Service. Yogyakarta: ANDI.

Tjiptono, F dan Chandra, G. 2016. Service, Quality, dan Satisfaction. Yogyakarta: ANDI.

Umar, Husein. 2003. Metode Riset Perilaku Konsumen Jasa. Jakarta: Ghalia Indonesia.

Wijayaningratri, Chatrin Surya dan Budiyanto. 2015. Pengaruh Fasilitas, Lokasi dan Pelayanan

Terhadap Kepuasan Nasabah Bank Mega Syariah Walikukun. Jurnal Ilmu dan Riset Manajemen. Volume 4. Nomor 4.

Windarti, Tias dan Mariaty Ibrahim. 2017. Pengaruh Kualitas Produk dan Kualitas Pelayanan Terhadap Kepuasan Konsumen Produk Donat Madu (Studi Pada Konsumen CV. Donat Madu Cihanjuang-Pekanbaru). Jom FISIP. Volume 4. Nomor 2. 